\title{
Erythrocyte Incorporation of Iron by 56-Day-Old Infants Fed a ${ }^{58} \mathrm{Fe}$-Labeled Supplement
}

\author{
SAMUEL J. FOMON, EKHARD E. ZIEGLER, STEVEN E. NELSON, ROBERT E. SERFASS, AND \\ JOAN A. FRANTZ \\ Department of Pediatrics, College of Medicine, University of Iowa, Iowa City, Iowa 52242-1083 [S.J.F., \\ E.E.Z., S.E.N., J.A.F.] and Department of Nutrition, Iowa State University, Ames, Iowa 50010[R.E.S.]
}

\begin{abstract}
In an effort to obtain information about absorption of supplemental iron by breast-fed infants during the early months of life, we determined erythrocyte incorporation of a stable iron isotope, administered to 56-d-old breast-fed infants in the form of a ${ }^{58} \mathrm{Fe}$-labeled vitamin-iron supplement. Infants of similar age fed a milk-based formula low in iron (approximately $4 \mathrm{mg} / \mathrm{L}$ ) were also studied. The ${ }^{58} \mathrm{Fe}$-labeled vitamin-iron supplement was given between feedings. Fourteen days after administration of ${ }^{58} \mathrm{Fe}$, mean erythrocyte incorporation of the isotope was $7.8 \%$ of the dose by breast-fed infants and $4.4 \%$ of the dose by formulafed infants. The feeding-related difference was statistically significant, probably reflecting the greater quantities of inhibitors of
\end{abstract}

ABSTRACT
The term infant is born with a substantial amount of iron in storage sites, and iron stores are increased as the result of decrease in circulating erythrocytes during the early weeks of life. The quantity of storage iron is then sufficient to permit the nearly doubling of erythrocyte mass and muscle mass during the first 4 mo of life, but the transfer of iron from storage sites to active tissues largely depletes storage sites of iron unless exogenous iron is provided. We therefore consider it desirable to supplement the infant's diet with iron beginning soon after birth. This suggestion is not new. More more than $25 \mathrm{y}$ ago the Committee on Nutrition of the American Academy of Pediatrics (1), stated that "... the early use of fortified formula results in augmentation of iron stores which helps to prevent later development of iron deficiency." This recommendation for early feeding of iron-fortified formulas has been reaffirmed more recently $(2,3)$. We believe that for breast-fed infants as well as for formula-fed infants augmentation of iron stores should be promoted by early supplementation of iron-a view that is in conflict with other recommendations. The prevailing recommendation is that iron supplementation of breast-fed infant be begun at 4 to 6 mo of age $(3,4)$.

Received December 30, 1994; accepted May 5, 1995.

Correspondence and reprint requests: Samuel J. Fomon, M.D., Department of Pediatrics, College of Medicine, University of Iowa, 200 Hawkins Drive, Iowa City, Iowa $52242-1083$. iron absorption in the intestines of formula-fed infants. With mean iron intake from the ${ }^{58} \mathrm{Fe}$-labeled vitamin-iron supplement of $7.99 \mathrm{mg}$ for the breast-fed infants, erythrocyte incorporation of $7.8 \%$ of the dose corresponded to $0.62 \mathrm{mg}$, a value in the range of the estimated requirement for absorbed iron. We conclude that 2-mo-old breast-fed infants are able to absorb nutritionally significant amounts of iron from an iron supplement. (Pediatr Res 38: 373-378, 1995)

BV, blood volume

Abbreviations

IR, isotope ratio

Although we believe that it is important to augment iron stores, little is known about the extent to which iron is absorbed during the early months of life. The present study was undertaken to obtain information on this point. We studied 56-d-old breast-fed infants given a daily supplement of iron (approximately $7.5 \mathrm{mg} / \mathrm{d}$ ), and, as a surrogate for iron absorption, determined erythrocyte incorporation of iron using the stable isotope, ${ }^{58} \mathrm{Fe}$, as a label. To investigate further the substantially greater erythrocyte incorporation of ${ }^{58} \mathrm{Fe}$ by breast-fed than by formula-fed infants given a small dose of ${ }^{58} \mathrm{Fe}$ between feedings (5), we included in the present study a group of formula-fed infants.

\section{METHODS}

\section{Subjects}

Normal infants of either sex with gestational age 37 wk or more and birth weight $2500 \mathrm{~g}$ or more were enrolled during the first $30 \mathrm{~d}$ of life. The study procedures were explained to one or both parents, and written consent was obtained. The study protocol was reviewed and approved by the University of Iowa Committee on Research Involving Human Subjects.

We wished to study 15 breast-fed and 15 formula-fed infants. Sixteen breast-fed infants ( 8 male and 8 female) and 19 formula-fed infants ( 10 male and 9 female) were enrolled in the study. For various reasons that we consider to be irrelevant to 
this report, two infants in the breast-fed group and three in the formula-fed group dropped out before receiving the first ${ }^{58} \mathrm{Fe}$ dose. We had anticipated one or two dropouts after administration of ${ }^{58} \mathrm{Fe}$ and had therefore decided to administer ${ }^{58} \mathrm{Fe}$ to 16 infants per group. However, when 30 infants (14 breast-fed and 16 formula-fed) had received their ${ }^{58} \mathrm{Fe}$ doses and most had completed the study, the supply of ${ }^{58} \mathrm{Fe}$-labeled supplement was exhausted, and rather than preparing a new batch, we elected to discontinue enrollment.

\section{Study Design}

Beginning at the time of enrollment (on or before $30 \mathrm{~d}$ of age), parents of breast-fed and formula-fed infants were provided a supply of Vi-Daylin ADC Vitamins + Iron Drops (Ross Laboratories, Columbus, $\mathrm{OH}$ ) and were instructed to give the infant $0.75 \mathrm{~mL}$ daily, providing (based on label claim) approximately $7.5 \mathrm{mg}$ of iron in the form of ferrous sulfate, 1125 IU of vitamin A, $300 \mathrm{IU}$ of vitamin D, and $26 \mathrm{mg}$ of ascorbic acid. This preparation will be referred to as the vitamin-iron supplement. The vitamin-iron supplement was measured with a $2-\mathrm{mL}$ syringe, which we provided, and administered directly into the infant's mouth. To provide an estimate of iron intake from the vitamin-iron supplement, we determined the iron concentration of the supplement and weighed back the bottles at $56 \mathrm{~d}$ of age.

Beginning at $56 \mathrm{~d}$ of age $( \pm 2 \mathrm{~d})$, the vitamin-iron supplement was withheld, and each infant visited the Lora N. Thomas Pediatric Metabolic Unit on three consecutive days. On each day the infant was given a dose of the vitamin-iron supplement labeled with ${ }^{58} \mathrm{Fe}$. Beginning on the day after the third dose of ${ }^{58} \mathrm{Fe}$-labeled vitamin-iron supplement, a supply of Vi-Daylin ADC Vitamins Drops (Ross Laboratories) (without iron) was given to breast-fed infants, and parents were instructed to give $0.75 \mathrm{~mL}$ daily at least until the end of the study at $84 \mathrm{~d}$ of age. After the last of the three doses of ${ }^{58} \mathrm{Fe}$-labeled vitamin-iron supplement, mothers of breast-fed infants were permitted to give supplemental feedings of a milk-based formula (Similac, Ross Laboratories) with low iron concentration, or to substitute feeding of this formula for breast feeding. Formula-fed infants continued to be formula fed and received no further supplement.

A baseline sample of blood was obtained by heel-stick at 56 $\mathrm{d}$ of age before the first dose of ${ }^{58} \mathrm{Fe}$-labeled supplement, and follow-up blood samples were obtained at 70 and $84 \mathrm{~d}$. Blood was collected in heparinized Microvette tubes (CB $1000 \mathrm{~S}$, Sarstedt, Inc., Newton, NC), and plasma was separated from cells within $30 \mathrm{~min}$ of blood collection.

\section{Feedings}

Breast-fed infants. Before enrollment in the study, infants were exclusively breast-fed, except for one infant who had received two small formula feedings (about $10 \mathrm{~mL}$ ) while in the hospital after birth. From the time of enrollment until $59 \mathrm{~d}$ of age all were exclusively breast-fed.

Formula-fed infants. From birth until the time of enrollment, all but four infants were fed various formulas. These four infants had been breast-fed for 3, 7, 10, and $26 \mathrm{~d}$, respectively, and then fed various formulas. From the time of enrollment until completion of the study at $84 \mathrm{~d}$ of age, infants were fed Similac with low iron content. Two lots of formula were used, one providing $4.0 \mathrm{mg}$ of iron per liter and the other providing $3.2 \mathrm{mg}$ of iron per liter.

\section{Administration of ${ }^{58} \mathrm{Fe}$}

On each of 3 consecutive days beginning at $56 \mathrm{~d}$ of age $( \pm 2$ d), infants were given a dose of Vi-Daylin ADC Vitamins $+\mathrm{Fe}$ Drops labeled with ${ }^{58} \mathrm{Fe}$. Enriched ${ }^{58} \mathrm{Fe}$ was obtained as elemental iron from U.S. Services Inc. (Summit, NJ). Its isotopic composition was (weight \%): $93.243 \%{ }^{58} \mathrm{Fe}, 6.593 \%{ }^{57} \mathrm{Fe}$, $0.155 \%{ }^{56} \mathrm{Fe}$, and $0.009 \%{ }^{54} \mathrm{Fe}$. It was converted to ferrous sulfate as described previously (6). Preparation of ${ }^{58} \mathrm{Fe}$ enriched Vi-Daylin ADC Vitamins + Iron Drops was as follows: $52.68 \mathrm{mg}$ of ${ }^{58} \mathrm{Fe}$-enriched iron as ferrous sulfate were dissolved in the vitamin-iron supplement $(8.48 \mathrm{mg}$ of iron per $\mathrm{g}$ of solution) to produce $84.97 \mathrm{~g}$ of a solution containing (per g) $9.03 \mathrm{mg}$ of iron, including $0.58 \mathrm{mg}$ of ${ }^{58} \mathrm{Fe}$ and (label claim) $32 \mathrm{mg}$ of ascorbic acid. The solution was stored in a nitrogenpurged rubber-stoppered vial.

The ${ }^{58} \mathrm{Fe}$-labeled supplement was given between 0900 and $1300 \mathrm{~h}$, at least $3 \mathrm{~h}$ after the last feeding and at least $1 \mathrm{~h}$ before the subsequent feeding. Approximately $0.8 \mathrm{~mL}$ of the labeled supplement was drawn up into a tared syringe and weighed. The mean amount of labeled iron administered to breast-fed infants was 7.99 (SD 0.39) $\mathrm{mg}$ per dose, and the mean amount administered to formula-fed infants was 8.10 (SD 0.18) $\mathrm{mg}$ per dose. The contents of the syringe were delivered directly into the infant's mouth and followed immediately by two $5-\mathrm{mL}$ rinses of the syringe with a $5 \%$ solution of glucose in water, delivered from the syringe directly into the infant's mouth. The infants were closely observed to detect drooling from the mouth immediately after administration. When drooling of brown-colored supplement occurred, the amount was quantitated by weighing the preweighed cellulose bib. Drooling of (clear) rinse fluid occurred not infrequently, but the amount was not quantitated because we considered it unlikely to involve appreciable loss of label. Any regurgitation during the hour after administration of ${ }^{58} \mathrm{Fe}$ was recorded by the mother.

\section{Laboratory Analyses}

Blood was analyzed for $\mathrm{Hb}$ concentration by Coulter Counter, model M430 (Coulter Electronics, Inc., Hialeah, FL), and plasma for ferritin concentration by RIA using the RAINEN Assay System kit (catalog no. NEA-078, DuPont, Billerica, MA) in the first 40 determinations and, when the RAINEN assay was no longer available, the Quantimune kit (catalog no. 190-2001, Bio-Rad Laboratories, Hercules, CA) in the remaining 49 determinations. Because the RAINEN assay gave systematically lower values in parallel determinations, values obtained with the RAINEN assay were multiplied by a factor of 1.15 .

The ${ }^{58} \mathrm{Fe} /{ }^{57} \mathrm{Fe}$ IR was determined by inductively coupled plasma mass spectrometry. Briefly, aliquots of packed erythrocytes that contained between 20 and $100 \mu \mathrm{g}$ of iron were decomposed with concentrated $(16 \mathrm{~mol} / \mathrm{L})$ nitric acid and 
hydrogen peroxide in closed vessels in a microwave digestion apparatus (Milestone mls 1200 mega, Buck Scientific, Inc., East Norwalk, CT). Four milliliters of nitric acid $(10 \mathrm{~mol} / \mathrm{L})$ were added to the digestate, and iron was selectively extracted with two $4-\mathrm{mL}$ aliquots of xylene that contained $0.5 \mathrm{~mol} / \mathrm{L}$ thenoyltrifluoroacetone (7). The xylene was stripped of its iron by addition of $3 \mathrm{~mL}$ of concentrated $(12 \mathrm{~mol} / \mathrm{L})$ hydrochloric acid, and the acid was evaporated at a temperature below $150^{\circ} \mathrm{C}$. The iron chloride that remained was brought to an iron concentration of $4 \mathrm{mg} / \mathrm{L}$ by dissolution in the appropriate volume of dilute $(0.16 \mathrm{~mol} / \mathrm{L})$ nitric acid. Aliquots of this solution were introduced into an inductively coupled plasma mass spectrometer (Finnigan Sola, Finnigan MAT, Ltd., Hemel Hempstead, UK) in alternation with a reference solution at similar concentration prepared from certified isotopic reference iron (IRRM-014, Institute for Reference Materials and Measurements, Geel, Belgium). Mass channels that encompassed 57 and 58 nominal atomic mass units were monitored alternately, and measured ratios of ${ }^{58} \mathrm{Fe}$ to ${ }^{57} \mathrm{Fe}$ were calculated by the instrument software as specified in the application program for the IR mode of operation. The mean of the measured ratios for the reference solution was used to calculate a normalization factor $(N)$ for each instrumental run:

$$
N=0.1330 / \text { mean of measured ratios for reference solution, }
$$

where 0.1330 is the certified ${ }^{58} \mathrm{Fe} /{ }^{57} \mathrm{Fe}$ ratio in the isotopic reference iron. Normalized ratios were calculated as follows:

\section{Normalized sample ratio $=N \times$ measured sample ratio.}

Normalization factors varied from day to day and were between 0.9900 and 1.0100. The precision of measurement for a series of 10 consecutive ratio acquisitions on each sample was between 0.2 and $0.5 \%$ relative SD.

\section{Calculation of Quantity of Administered ${ }^{58} \mathrm{Fe}$ Incorporated into Erythrocytes}

Calculations differ slightly from those used previously $(5,8$, 9) because atom IR rather than mass IR has been used. The quantity of administered ${ }^{58} \mathrm{Fe}$ label incorporated into erythrocytes $\left({ }^{58} \mathrm{Fe}_{\text {inc }}^{*}\right)$ at a specified time $t$ after administration of the dose was calculated as follows:

$$
{ }^{58} \mathrm{Fe}_{\text {inc }}^{*}=\frac{\mathrm{IR}_{t}-\mathrm{IR}_{\mathrm{o}}}{\mathrm{IR}_{\mathrm{o}}} \times \mathrm{Fe}_{\mathrm{circ}} \times \frac{0.2819 \times 57.933}{100 \times 55.845,}
$$

where ${ }^{58} \mathrm{Fe}_{\text {inc }}^{*}$ is expressed in $\mathrm{mg}, \mathrm{IR}_{t}$ is the determined ${ }^{58} \mathrm{Fe} /$ ${ }^{57} \mathrm{Fe}$ IR at time $t$ after dosing, IR is the determined baseline ratio, $\mathrm{Fe}_{\text {circ }}$ is the quantity of total circulating iron $(\mathrm{mg})$ at time $t$, and 0.2819 is the natural abundance (atom \%) of ${ }^{58} \mathrm{Fe}, 57.933$ is the atomic weight of ${ }^{58} \mathrm{Fe}$, and 55.845 is the atomic weight of natural $\mathrm{Fe}$.

The quantity of total circulating iron (mg) was estimated as follows:

$$
\mathrm{Fe}_{\mathrm{circ}}=\mathrm{BV} \times \mathrm{Hb} \times 3.47
$$

where $\mathrm{BV}$ is blood volume in liters, $\mathrm{Hb}$ is $\mathrm{Hb}$ concentration in $\mathrm{g} / \mathrm{L}$, and 3.47 is the concentration of iron in $\mathrm{Hb}(\mathrm{mg} / \mathrm{g})$. We assumed blood volume to be $65 \mathrm{~mL}$ per $\mathrm{kg}$ of body weight, a value almost identical to the mean value of $66 \mathrm{~mL} / \mathrm{kg}$ reported by Bratteby (10) for eight normal infants between 100 and 138 d of age.

\section{Statistical Analysis}

Descriptive statistics and parametric and nonparametric statistical analyses were performed using SAS version 6.08 (SAS Institute, Cary, NC). Erythrocyte incorporation values were compared by analysis of variance and Wilcoxson rank sum test. The effect of feeding on ${ }^{58} \mathrm{Fe}$ erythrocyte incorporation was also examined by covariate analysis, using plasma ferritin as the covariate. Results of the applicable parametric and nonparametric tests were consistent. Only the results of the parametric tests are presented. Similarly, we carried out the analyses both with arithmetic and geometric means and found similar levels of significance. Only data concerning arithmetic means are presented. Gender-related differences were not significant and gender was eliminated as a factor in the statistical analyses. Statistical significance was set at $\alpha=0.05$.

\section{RESULTS}

Thirty infants received the three doses of ${ }^{58} \mathrm{Fe}$-labeled supplement. One infant (formula-fed) had mild diarrhea and temperature elevation on the first day of ${ }^{58} \mathrm{Fe}$ administration and regurgitated an unquantified amount of labeled supplement after the second ${ }^{58} \mathrm{Fe}$ administration. Data for this infant are not presented. For the remaining 29 infants ( 14 breast-fed and 15 formula-fed), body weight, $\mathrm{Hb}$, and plasma ferritin concentrations and the ${ }^{58} \mathrm{Fe} /{ }^{57} \mathrm{Fe}$ IR at ages 56 (baseline), 70, and $84 \mathrm{~d}$ of age are presented in Table 1 . Percent erythrocyte incorporation of iron 14 and $28 \mathrm{~d}$ after administration (at ages 70 and $84 \mathrm{~d}$, respectively) is also presented.

After administration of the ${ }^{58} \mathrm{Fe}$-labeled dose of supplement, drooling of measurable amounts of brown-stained supplement, presumably containing ${ }^{58} \mathrm{Fe}$, occurred on one or more occasions in 8 breast-fed and 10 formula-fed infants. In two of the formula-fed infants drooling occurred on each of 3 d totaling $1.1 \mathrm{~g}$ (subject 56371) and $0.8 \mathrm{~g}$ (subject 5638), respectively. In the other 16 infants, total measured losses of brown-stained fluid totaled $0.4 \mathrm{~g}$ or less (mean $0.24 \mathrm{~g}$ ).

Because the concentration of ${ }^{58} \mathrm{Fe}$ in the brown-stained fluid lost by the infants was likely to have been less than the concentration in the supplement as administered, we have presented in the table data based on quantity of ${ }^{58} \mathrm{Fe}$ administered, but have excluded data from subjects 5637 and 5638 in calculating the means and carrying out the statistical calculations. An estimate of the possible error introduced by failing to correct for the measured losses will be presented.

For the 27 infants whose data are included in the mean values in the table, mean birth weight was $3680 \mathrm{~g}$ (range 3345-4420 g) for breast-fed male infants, $3487 \mathrm{~g}$ (3060-4155 g) for breast-fed female infants, $3574 \mathrm{~g}(2850-4080 \mathrm{~g})$ for formula-fed male infants, and $3267 \mathrm{~g}$ (2705-3940 g) for formula-fed female infants. Mean age at the time of enrollment was $17.6 \mathrm{~d}$ for breast-fed infants and $12.4 \mathrm{~d}$ for formula-fed infants. On a gender- and feeding-specific basis, gains in 
Table 1. Subject characteristics and erythrocyte incorporation of iron

\begin{tabular}{|c|c|c|c|c|c|c|c|c|c|c|c|c|c|c|c|}
\hline \multicolumn{2}{|c|}{ Subject } & \multicolumn{4}{|c|}{56 days } & \multicolumn{5}{|c|}{70 days } & \multicolumn{5}{|c|}{84 days } \\
\hline Number & Sex & $\begin{array}{c}\text { Weight } \\
\text { (g) }\end{array}$ & $\begin{array}{c}\mathrm{Hb} \\
(\mathrm{g} / \mathrm{L}) \\
\end{array}$ & $\begin{array}{c}\text { Ferritin } \\
(\mu \mathrm{g} / \mathrm{L})\end{array}$ & $\mathrm{IR}_{0}{ }^{*}$ & $\begin{array}{l}\text { Weight } \\
\text { (g) }\end{array}$ & $\begin{array}{c}\mathrm{Hb} \\
(\mathrm{g} / \mathrm{L})\end{array}$ & $\begin{array}{l}\text { Ferritin } \\
(\mu \mathrm{g} / \mathrm{L})\end{array}$ & $\mathrm{IR}_{14}{ }^{*}$ & $\begin{array}{c}\text { Incorp. } \\
(\%)\end{array}$ & $\begin{array}{l}\text { Weight } \\
(\mathrm{g})\end{array}$ & $\begin{array}{c}\mathrm{Hb} \\
(\mathrm{g} / \mathrm{L})\end{array}$ & $\begin{array}{c}\text { Ferritin } \\
(\mu \mathrm{g} / \mathrm{L})\end{array}$ & $\mathrm{IR}_{28}{ }^{*}$ & $\begin{array}{c}\text { Incorp. } \\
(\%)\end{array}$ \\
\hline \multicolumn{16}{|c|}{ Breast-fed } \\
\hline 5652 & M & 5300 & 115 & 118 & 0.1318 & 5800 & 111 & 210 & 0.1792 & 10.1 & 6210 & 112 & 115 & 0.1729 & 9.4 \\
\hline 5653 & $\mathrm{~F}$ & 5950 & & 78 & 0.1332 & 6440 & 110 & 103 & 0.1680 & 7.9 & 6780 & 107 & 85 & 0.1627 & 6.9 \\
\hline 5654 & $\mathrm{~F}$ & 4980 & 110 & 83 & 0.1316 & 5430 & 107 & 69 & 0.1868 & 10.0 & 5950 & 102 & 53 & 0.1921 & 11.5 \\
\hline 5655 & F & 4980 & 120 & 280 & 0.1341 & 5250 & 110 & 290 & 0.1554 & 4.3 & 5370 & 118 & 218 & 0.1643 & 6.5 \\
\hline 5656 & $\mathrm{~F}$ & 5680 & 110 & 281 & 0.1316 & 6120 & 112 & 425 & 0.1589 & 5.7 & 6600 & 113 & 345 & 0.1603 & 6.6 \\
\hline 5657 & $\mathrm{M}$ & 5560 & 112 & 220 & 0.1324 & 5890 & 108 & & 0.1694 & 7.5 & 6400 & 115 & 127 & 0.1634 & 7.2 \\
\hline 5658 & $\mathrm{~F}$ & 5550 & 122 & 235 & 0.1319 & 6190 & 124 & 265 & 0.1760 & 10.6 & 6560 & 122 & 182 & 0.1646 & 8.1 \\
\hline 5659 & M & 5730 & 124 & 155 & 0.1330 & 6110 & 123 & 140 & 0.1641 & 7.5 & 6270 & 117 & 140 & & \\
\hline 5661 & $\mathrm{~F}$ & 5100 & 108 & & 0.1339 & 5480 & 112 & & 0.1641 & 6.2 & 5780 & 115 & 100 & 0.1639 & 6.6 \\
\hline 5662 & $\mathrm{~F}$ & 5020 & 112 & 380 & 0.1339 & 5540 & 120 & & 0.1466 & 2.9 & 5950 & 110 & 240 & 0.1472 & 3.0 \\
\hline 5663 & M & 6120 & 111 & 132 & 0.1315 & 6540 & 106 & 178 & 0.1798 & 10.3 & 6770 & 118 & 138 & 0.1966 & 16.2 \\
\hline 5664 & $\mathrm{~F}$ & 5350 & 124 & 230 & 0.1317 & 5720 & 122 & 200 & 0.1739 & 9.1 & 6040 & 120 & 134 & 0.1781 & 10.4 \\
\hline 5666 & M & 5900 & & & 0.1336 & 6520 & 100 & 103 & 0.1702 & 9.4 & 6790 & 100 & 56 & 0.1680 & 9.3 \\
\hline 5667 & $\mathrm{M}$ & 5860 & 124 & 187 & 0.1336 & 6450 & 105 & 139 & 0.1657 & 7.1 & 6810 & 114 & 83 & 0.1653 & 8.0 \\
\hline Mean & & 5506 & 116 & 198 & 0.1327 & 5963 & 112 & 193 & 0.1684 & 7.8 & 6306 & 113 & 144 & 0.1692 & 8.4 \\
\hline $\mathrm{SD}$ & & 388 & 6 & 90 & 0.0010 & 439 & 7 & 103 & 0.0106 & 2.4 & 445 & 6 & 80 & 0.0132 & 3.1 \\
\hline \multicolumn{16}{|c|}{ Formula-fed } \\
\hline 5627 & $M$ & 4785 & 105 & 37 & 0.1354 & 5410 & 106 & 37 & 0.2118 & 15.5 & 5880 & 110 & 17 & 0.2027 & 15.4 \\
\hline 5630 & M & 6560 & 118 & 263 & 0.1330 & 6940 & 111 & 244 & 0.1444 & 2.5 & 7330 & 120 & 169 & 0.1442 & 2.8 \\
\hline 5631 & $\mathrm{~F}$ & 5220 & 110 & 36 & 0.1328 & 5570 & 112 & 28 & 0.1580 & 4.7 & 5790 & 112 & 39 & 0.1608 & 5.4 \\
\hline 5632 & M & 6020 & 132 & 274 & 0.1349 & 6310 & 124 & 320 & 0.1438 & 2.4 & 6700 & 117 & 217 & 0.1430 & 2.2 \\
\hline 5633 & $\mathrm{~F}$ & 4200 & 108 & 146 & 0.1345 & 4560 & 104 & 102 & 0.1564 & 3.3 & 4820 & 108 & & 0.1572 & 3.8 \\
\hline 5634 & $\mathrm{~F}$ & 4760 & 104 & 201 & 0.1339 & 5320 & 92 & 149 & 0.1576 & 3.6 & 5710 & 106 & & & \\
\hline 5636 & $\mathrm{~F}$ & 4070 & 94 & 144 & 0.1347 & 4370 & 100 & 101 & 0.1508 & 2.3 & 4600 & 106 & 101 & 0.1526 & 2.8 \\
\hline 5637 & $\mathrm{~F}$ & 4640 & 106 & 67 & 0.1320 & 5030 & 107 & 126 & 0.1443 & 1.7 & 5230 & 106 & 69 & 0.1455 & 2.0 \\
\hline 5638 & $\mathrm{M}$ & 5170 & 109 & & 0.1354 & 5380 & 112 & 155 & 0.1472 & 2.5 & 5650 & 110 & 148 & 0.1438 & 1.9 \\
\hline 5639 & $\mathrm{~F}$ & 4960 & 106 & 157 & 0.1355 & 5360 & 114 & 180 & 0.1730 & 7.4 & 5640 & 118 & 163 & 0.1735 & 8.2 \\
\hline 5640 & M & 6550 & 96 & 108 & 0.1352 & 7120 & 95 & 93 & 0.1574 & 5.0 & 7660 & 97 & 100 & 0.1578 & 5.5 \\
\hline 5642 & $M$ & 5690 & 112 & 113 & 0.1323 & 6110 & 108 & 72 & 0.1483 & 2.9 & 6580 & 114 & 67 & 0.1458 & 2.8 \\
\hline 5643 & $\mathrm{~F}$ & 5060 & 119 & & 0.1352 & 5360 & 104 & 345 & 0.1386 & 0.8 & 5810 & 108 & 210 & & \\
\hline 5644 & M & 5230 & 102 & 110 & 0.1331 & 5580 & 112 & 167 & & & 5940 & 112 & 76 & 0.1612 & 5.6 \\
\hline 5645 & $\mathrm{M}$ & 6010 & 90 & 89 & 0.1331 & 6630 & 90 & 143 & 0.1481 & 2.6 & 7010 & 101 & 69 & 0.1450 & 2.4 \\
\hline Mean* & & 5317 & 107 & 140 & 0.1341 & 5742 & 106 & 152 & 0.1573 & 4.4 & 6113 & 110 & 112 & 0.1585 & 5.2 \\
\hline S.D. & & 805 & 11 & 76 & 0.0011 & 841 & 10 & 99 & 0.0194 & 3.9 & 907 & 7 & 68 & 0.0174 & 3.9 \\
\hline
\end{tabular}

${ }^{*} \mathrm{IR}_{0}$ refers to normalized ${ }^{58} \mathrm{Fe} /{ }^{57} \mathrm{Fe}$ isotope ratio at $56 \mathrm{~d}$ (baseline); $\mathrm{IR}_{14}$ refers to the ratio at $70 \mathrm{~d}$, and $\mathrm{IR}_{28}$ at $84 \mathrm{~d}$.

** Mean values and SD values exclude data for subjects 5637 and 5638 , who had large drooling losses.

weight and length from 28 to $84 \mathrm{~d}$ of age were similar to gains in weight and length of a larger group of infants studied previously (11). (Means for birth weight and gains in weight and length of the formula-fed infants are nearly the same if calculated without the exclusion of subjects 5637 and 5638).

Although not statistically significant, mean concentrations of $\mathrm{Hb}$ and serum ferritin at ages 56,70 , and $84 \mathrm{~d}$ were somewhat less for formula-fed than for breast-fed infants. However, $\mathrm{Hb}$ concentrations less than $100 \mathrm{~g} / \mathrm{L}$ in three formula-fed infants (subjects 5636, 5640, and 5645) were not associated with low concentrations of serum ferritin and therefore do not suggest the presence of iron deficiency.

Mean erythrocyte incorporation of the ${ }^{58} \mathrm{Fe}$ label $14 \mathrm{~d}$ after administration of the isotope (i.e. at $70 \mathrm{~d}$ of age) was $7.8 \%$ (SD 2.4) of the dose by breast-fed infants and 4.4\% (SD 3.9\%) of the dose by formula-fed infants. The difference was statistically significant $(p=0.012)$. Twenty-eight days after administration of the ${ }^{58} \mathrm{Fe}$ label (i.e. at $84 \mathrm{~d}$ of age), mean erythrocyte incorporation of the isotope was $8.4 \%$ (SD $3.1 \%$ ) of the dose by breast-fed infants and 5.2\% (SD 3.9\%) of the dose by formula-fed infants. The difference was statistically significant ( $p=0.033$ ).

We also calculated percent incorporation of ${ }^{58} \mathrm{Fe}$ with intakes corrected for drooling losses. These calculations were done with and without subjects 5637 and 5638 . With the inclusion of subjects 5637 and 5638 , corrected mean incorporation at $70 \mathrm{~d}$ was $8.3 \%$ (SD 2.5\%) by breast-fed and $4.4 \%$ (SD $3.6 \%)$ by formula-fed infants. The difference was statistically significant $(p<0.002)$. Excluding subjects 5637 and 5638, corrected mean incorporation at $70 \mathrm{~d}$ of age by formula-fed infants was $4.5 \%$ (SD 3.9\%). For the reason mentioned previously, the true percentages for incorporation of the ${ }^{58} \mathrm{Fe}$ label $14 \mathrm{~d}$ after administration of the isotope are likely to lie closer to the uncorrected values ( $7.8 \%$ for the breast-fed infants and $4.4 \%$ for the formula-fed infants) than to the corrected values ( 8.3 and $4.5 \%$, respectively). However, it is evident that corrected and uncorrected results are quite similar.

The relation of percent erythrocyte incorporation of the ${ }^{58} \mathrm{Fe}$ label (uncorrected) at $70 \mathrm{~d}$ of age to plasma ferritin concentra- 
tion (average of 56- and 70-d values) is presented in Figure 1 for the 25 subjects. Subject 5661 was excluded because there was no serum ferritin value and subject 5644 was excluded because erythrocyte incorporation of ${ }^{58} \mathrm{Fe}$ at $70 \mathrm{~d}$ of age was not determined. It is evident that the slopes of the regressions were similar for the two feeding groups. The correlation of ${ }^{58} \mathrm{Fe}$ erythrocyte incorporation on plasma ferritin concentration was statistically significant for breast-fed infants $(r=0.488, p$ $=0.008)$ but not for formula-fed infants $(r=0.290, p=$ 0.071 ). Adjusting ${ }^{58} \mathrm{Fe}$ incorporation for ferritin concentration by covariance analysis, the difference in incorporation between breast-fed and formula-fed infants was highly significant $(p<$ 0.001).

Iron nutritional status and estimated iron intake. At $56 \mathrm{~d}$ of age, mean $\mathrm{Hb}$ concentration of the breast-fed infants was significantly greater than that of the formula-fed infants $(p=$ 0.03 ). At 70 and $84 \mathrm{~d}$ of age the differences were not significant ( $p=0.055$ and 0.22 , respectively). Mean plasma ferritin concentrations of the breast-fed infants were somewhat greater than those of the formula-fed infants, but the differences were not significant at $56 \mathrm{~d}$ of age $(p=0.10)$, nor at ages 70 and 84 $\mathrm{d}(p=0.34$ and 0.30 , respectively). Concentrations of $\mathrm{Hb}$ and plasma ferritin were similar whether or not data on subjects 5637 and 5638 were included.

Weighing back of the bottles of the vitamin-iron supplement indicated that mean intake of iron from this source was 5.9 $\mathrm{mg} / \mathrm{d}$ (range $2.7-8.1 \mathrm{mg} / \mathrm{d}$ ) by the 14 breast-fed infants and 6.6 $\mathrm{mg} / \mathrm{d}$ (range 1.2-9.7 $\mathrm{mg} / \mathrm{d}$ ) by the 13 formula-fed infants. Assuming an iron concentration of $0.45 \mathrm{mg} / \mathrm{L}$ for human milk and average milk consumption of $0.7 \mathrm{~L} / \mathrm{d}$, dietary iron intake before $56 \mathrm{~d}$ of age may have been about $0.3 \mathrm{mg} / \mathrm{d}$. Mean total intake of iron by the breast-fed infants was therefore about 6.2 $\mathrm{mg} / \mathrm{d}$. Dietary iron intake by the formula-fed infants (from iron concentration of the formulas and the amount consumed, as determined by weighing of the formula bottles) between 28 and $56 \mathrm{~d}$ of age was $3.0 \mathrm{mg} / \mathrm{d}$ (range 2.2 to $3.9 \mathrm{mg} / \mathrm{d}$ ). Thus, mean total iron intake by the formula-fed infants was about $9.6 \mathrm{mg} / \mathrm{d}$ (range 4.2 to 13.0 ). The greater availability of iron to the breast-fed infants (as indicated by greater erythrocyte incorporation) apparently more than compensated for their lower iron

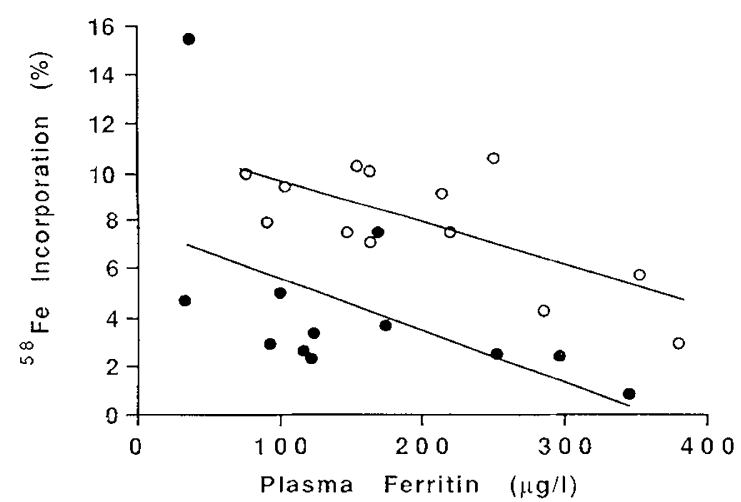

Figure 1. Relation between percent ${ }^{58} \mathrm{Fe}$ incorporation $14 \mathrm{~d}$ after administration of ${ }^{58} \mathrm{Fe}$, and plasma ferritin concentration (average of $56 \mathrm{~d}$ and $70 \mathrm{~d}$ values) in breast-fed $(O)$ and formula-fed $(\bullet)$ infants. The regression lines are indicated for breast-fed $(y=11.40-0.01758 \cdot x)$ and formula-fed $(y=7.71-$ $0.02121 \cdot x$ ) infants. intake, leading to more satisfactory iron nutritional status of the breast-fed than of the formula-fed infants.

\section{DISCUSSION}

In an effort to obtain information about absorption of iron by normal infants during the early months of life, we determined erythrocyte incorporation of the stable iron isotope, ${ }^{58} \mathrm{Fe}$, administered in the form of a vitamin-iron supplement to 56 -d-old infants. The ${ }^{58} \mathrm{Fe}$-labeled vitamin-iron supplement was given $3 \mathrm{~h}$ after the previous feeding to breast-fed infants and to infants fed a milk-based formula low in iron (3-4 mg $\mathrm{Fe} / \mathrm{L})$. For at least $28 \mathrm{~d}$ before administration of the ${ }^{58} \mathrm{Fe}$ labeled supplement, all parents were requested to give their infants approximately $7.5 \mathrm{mg} / \mathrm{d}$ of iron in the form of ferrous sulfate. With few exceptions, compliance with the instructions appeared to be good.

Fourteen days after administration of the supplement, mean erythrocyte incorporation of ${ }^{58} \mathrm{Fe}$ by breast-fed infants was $7.8 \%$ of the dose when uncorrected for drooling losses and $8.3 \%$ of the dose when corrected for drooling losses. With mean iron intake from the ${ }^{58} \mathrm{Fe}$-labeled supplement of $7.99 \mathrm{mg}$ for the breast-fed infants, erythrocyte incorporation of $7.8 \%$ of the dose corresponded to $0.62 \mathrm{mg}$. Even if one ignores the quantity of iron that is presumably absorbed but not promptly incorporated into erythrocytes, the amount incorporated into erythrocytes $(0.62 \mathrm{mg})$ is in the range of 0.55 to $0.75 \mathrm{mg} / \mathrm{d}$ estimated to be the infant's mean requirement for absorbed iron (12). Thus, at least by 2 mo of age, administration of about 7.5 mg of supplemental iron to breast-fed infants can meet the requirement for absorbed iron.

Erythrocyte incorporation of the ${ }^{58} \mathrm{Fe}$ label by formula-fed infants was significantly less than that by breast-fed infants. Fourteen days after administration of the supplement, mean erythrocyte incorporation of ${ }^{58} \mathrm{Fe}$ by formula-fed infants was $4.4 \%$ of the dose when uncorrected for drooling losses and $4.5 \%$ of the dose when corrected for drooling losses. The present findings therefore confirm our previous findings (5) that incorporation of iron by breast-fed infants is greater than by formula-fed infants even when the dose is given $3 \mathrm{~h}$ after a feeding of milk or formula. The lesser extent of erythrocyte incorporation of iron by formula-fed infants presumably reflects difference in extent of absorption, resulting primarily from the presence of greater quantities of known inhibitors of iron absorption (calcium and bovine milk proteins) (13-20) in the intestinal tracts of the formula-fed infants.

For each feeding group, erythrocyte incorporation of iron was inversely correlated with plasma ferritin concentration. Nevertheless, although plasma ferritin concentration of the breast-fed infants was greater than that of formula-fed infants, erythrocyte incorporation of iron was greater by the breast-fed infants. Thus, to the extent that plasma ferritin concentration reflects iron stores and erythrocyte incorporation of iron reflects iron absorption, factors inhibiting iron absorption appeared to be more important than iron stores in determining the extent of absorption.

The percentage erythrocyte incorporation of iron from the ${ }^{58} \mathrm{Fe}$-labeled vitamin-iron supplement providing approximately 
$8 \mathrm{mg}$ of iron was less than from the small test dose (approximately $0.6 \mathrm{mg}$ of iron) used in the previous study (7.8 versus $20.0 \%$ for breast-fed infants, and 4.4 versus $6.9 \%$ for formulafed infants). This finding was anticipated because of the previously noted inverse relation between quantity of iron ingested and percentage absorption (21) or percentage erythrocyte incorporation (22) of iron.

It is generally assumed that in normal and iron-deficient adults in the absence of bone marrow failure, ineffective erythropoiesis, aplastic anemia, hemolytic anemia or iron overload, $80 \%$ (23) or $90 \%$ (20) of an absorbed iron isotope is incorporated into erythrocytes in $14 \mathrm{~d}$. Few data are available concerning the extent of erythrocyte incorporation of absorbed iron by infants. Studies in which radioiron was administered i.v. to infants of various ages (24) indicated that administration to infants from 2 to $8 \mathrm{wk}$ of age generally resulted in less than $80 \%$ erythrocyte incorporation of the iron isotope. Moreover, sequential studies of reticulocyte counts and erythropoietic activity of the bone marrow indicated that erythropoiesis in normal term infants falls to low levels by $9 \mathrm{~d}$ of age, has begun to increase by $29 \mathrm{~d}$ of age, and reaches relatively high levels by $59 \mathrm{~d}$ of age (25). It therefore seems likely that from 2 wk until nearly $8 \mathrm{wk}$ of age, erythrocyte incorporation of an administered dose of iron will be less than was observed in the 8 -wk-old infants in the present study. Whether absorption of iron as well as erythrocyte incorporation of iron is less before 8 wk of age, a period of relatively low hematopoietic activity, is unknown.

We conclude that administration of an iron supplement to breast-fed infants during the early months of life will appreciably augment body iron stores and decrease the likelihood that iron deficiency will develop later in the first year. A detailed consideration of the arguments for and against administration of iron to breast-fed infants before 4 mo of age is beyond the scope of the present communication.

\section{REFERENCES}

1. Committee on Nutrition, American Acadcmy of Pediatrics 1969 Iron balance and requirements in infancy. Pediatrics 43:134-142

2. Committee on Nutrition, American Academy of Pediatrics 1992 The use of whole cow's milk in infancy. Pediatrics 89:1105-1109
3. Earl R, Woteki, CE (eds) 1993 Iron Deficiency Anemia: Recommended Guidelines for the Prevention, Detection, and Management Among U.S. Children and Women of Childbearing Age. National Academy Press, Washington, DC, p 20

4. Committee on Nutrition, American Academy of Pediatrics; Barness, LA (ed) 1993 Pediatric Nutrition Handbook. American Academy of Pediatrics, Elk Grove Village, IL, p 231

5. Fomon SJ, Ziegler EE, Nelson SE 1993 Erythrocyte incorporation of ingested ${ }^{58} \mathrm{Fe}$ by 56-day-old breast-fed and formula-fed infants. Pediatr Res 33:573-576

6. Janghorbani MJ, Ting BTG, Fomon SJ 1986 Erythrocyte incorporation of ingested stable isotope of iron $\left({ }^{58} \mathrm{Fe}\right)$. Am J Hematol 21:277-288

7. Moore FL, Fairman WD, Ganchoff JG, Surak JG 1959 Selective liquid-liquid extraction of iron with 2-thenoyltrifluoroacetone-xylene. Anal Chem 31:1148-1151

8. Fomon SJ, Janghorbani M, Ting BTG, Ziegler EE, Rogers RR, Nclson SE, Ostedgaard LS, Edwards BB 1988 Erythrocyte incorporation of ingested 58-iron by infants. Pediatr Res 24:20-24

9. Fomon SJ, Ziegler EE, Rogers RR, Nelson SE, Edwards BB, Guy DG, Erve JC, Janghorbani $M 1989$ Iron absorption from infant foods. Pediatr Res 26:250-254

10. Bratteby L-E 1968 Studies on erythro-kinetics in infancy. XI. The change in circulating red cell volume during the first five months of life. Acta Paediatr Scand 57:215-224

11. Nelson SE, Rogers RR, Ziegler EE, Fomon SJ 1989 Gain in weight and length during early infancy. Early Hum Dev 19:223-239

12. Fomon, S.J. 1993 Iron. In: Nutrition of Normal Infants. Mosby, St. Louis, Chap 14, pp 239-260

13. Monsen ER, Cook JD 1976 Food iron absorption in human subjects. IV. The effects of calcium and phosphate salts on the absorption of nonheme iron. Am I Clin Nutr 29:1142-1148

14. Monsen ER, Cook JD 1979 Food iron absorption in human subjects. V. Effects of the major dietary constitutents of a semisynthetic meal. Am J Clin Nutr 32:804-808

15. Cook JD, Morck TA, Lynch SR 1981 The inhibitory effecl of soy products on nonheme iron absorption in man. Am J Clin Nutr 34:2622-2629

16. Hurrell RF, Lynch SR, Trinidad TP, Dassenko SA, Cook, JD 1988 Iron absorption in humans: Bovine serum albumin compared with beef muscle and egg white. Am J Clin Nutr 47:102-107

17. Hurrell RF, Furniss DE, Burri J, Whittaker P, Lynch SR, Cook JD 1989 Iron fortification of infant cereals: A proposal for the use of ferrous fumarate or ferrous succinate. Am J Clin Nutr 49:1274-1282

18. Hurrell RF, Berrocal R, Lynch SR, Dassenko SA, Cook JD 1990 The influence of bovine milk proteins on iron absorption in man. In: Hercberg $S$, Galan P, Dupin H (eds) Recent Knowledge on Iron and Folate Deficiencies in the World. INSERM Collog 197:265-273

19. Dawson-Hughes B, Seligson FH, Hughes VA 1986 Effects of calcium carbonate and hydroxyapatite on zinc and iron retention in postmenopausal women. Am J Clin Nutr 44:83-88

20. Hallberg L, Brune M, Erlandsson M, Sandberg A-S, Rossander-Hultén L 1991 Calcium: effect of different amounts on nonheme- and heme-iron absorption in humans. Am J Clin Nutr 53:112-119

21. Heinrich HC, Gabbe EE, Whang DH, Bender-Gotze Ch, Schafer KH 1975 Ferrous and hemoglobin ${ }^{59} \mathrm{Fe}$ absorption from supplemented cow milk in infants with normal and depleted iron stores. Z Kinderheilk 120:251-258

22. Bezwoda WR, Bothwell TH, Charlton RW, Torrance JD, MacPhail AP, Derman DP, Mayet F 1983 The relative dietary importance of haem and non-haem iron. S Afr Med J 64:552-556

23. Bothwell TH, Charlton RW, Cook JD, Finch CA (eds) 1979 Iron Metabolism in Man. Blackwell Scientific Publications, Oxford, pp 88-104, 431

24. Garby L, Sjölin S, Vuille J-C 1963 Studies on erythro-kinetics in infancy. III disappearance from plasma and red-cell uptake of radio-active iron injected intravenously. Acta Paediatr 52:537-553

25. Gairdner D, Marks J, Roscoe JD 1952 Blood formation in infancy. II. Normal erythropoiesis. Arch Dis Child 27:214-221 